\title{
IMAGEM E HISTÓRIA
}

Edmilson Menezes*

O homem é esta noite, este nada vazio que contém tudo em sua simplicidade; uma riqueza com um número infinito de representações, de imagens, nenhuma das quais surge precisamente a seu espírito ou que não estão sempre presentes. É a noite, a interioridade da natureza que aqui existe: o $S i$ puro. Em representações fantásticas é noite em volta; aqui surge então uma cabeça ensangüentada, lá um outro rosto branco; e desaparecem também bruscamente. É esta noite que percebemos quando olhamos um homem nos olhos: uma noite que se torna terrível; é a noite do mundo que então nos encara. O poder de tirar desta noite as imagens, ou de aí abandoná-las, (é isso) o fato de colocar-se a si próprio, a consciência interior, a ação, a cisão. ${ }^{1}$ Nesta passagem, o filósofo de Stuttgart chama à nossa atenção uma das mais intricadas e complexas aptidões humanas: a de evocar imagens. Uma cabeça coberta de sangue, um rosto pálido, surgem à mente de um dado homem revestidos, em muitos casos, de uma outra capacidade essencial ao vivente: a de sinalizar. "O delírio mais elaborado bem como a fantasia mais secreta e mais vaga são feitas de 'imagens' mas estas 'imagens' lá estão como representando outra coisa; possuem, portanto, uma função simbólica. Mas também, inversamente, o simbolismo pressupõe a capacidade imaginária. Pois pressupõe a capacidade de ver em uma coisa o que ela não é, de vêla diferente do que é." ${ }^{2} \mathrm{O}$ simbolismo requer a capacidade de estabelecer

*Edmilson Menezes é Doutor em Filosofia pela Unicamp e Professor do Departamento de Filosofia da UFS. 
liames permanentes entre dois termos, significante e significado, de maneira que um "representa" o outro.

Sendo assim, parece-nos que, de maneira geral, a dinâmica humana é a dinâmica eterna da conformidade entre significado e significante, uma decifração de códigos. Porém, uma pergunta, neste contexto, é pertinente: o que, na infinidade das estruturas possíveis, especifica um sistema simbólico, estabelece as relações canônicas prevalentes, orienta em uma direção das inúmeras possíveis todas as metáforas e metonímias abstratamente concebíveis? Qualquer resposta apresentada neste sentido não pode está desatrelada do imaginário. Um sentido surge aí desde as origens, que não é um sentido de real (referido ou percebido), que não é também racional, ou positivamente irracional, que não é nem verdadeiro nem falso, e, no entanto, é da origem da significação, e que é a criação imaginária própria da história, na qual e pela qual a história se constitui para começar.

É impossível, por isso, compreender o que foi e o que é a história humana sem o uso das imagens. Em muitos quadros da história universal, o real e o racional são insuficientes para explicar totalmente a radicalidade dos fenômenos ali presentes.

Um desses quadros, a descoberta da América, é muito significativo por se prestar à análise da incapacidade racional, com requintes de detalhes. Segundo o relato do frei Bartolomé de Las Casas (desembarcado na América central em 1502), o extermínio dos autóctones (muitas vezes dóceis e pacíficos) era praticado com apuro de crueldade e sarcasmo pelos espanhóis: "Faziam apostas sobre quem, de um só golpe de espada, fenderia e abriria um homem pela metade, ou quem, mais habilmente e mais destramente, de um só golpe the cortaria a cabeça, ou ainda melhor, as entranhas de um homem com um só golpe." ${ }^{3} \mathrm{Em}$ outro lugar, os olhos passivos do piedoso sacerdote ainda registram: "Os espanhóis gritavam que vinham em paz, garantindo-lhes que não lhes fariam nenhum mal e que, quanto a eles, que não fizessem guerra. Incontinenti, os índios cessaram a defesa e o facínora mandou então dizer aos espanhóis que tomassem os fortes da montanha e que uma vez tomados esses fortes, caíssem sobre os índios. Arremessaram-se então como tigres e leões sobre estes cordeiros tão dóceis, e passaram tantos a fio de espada que Ihes foi até preciso descansar; e após haverem, o capitão ordenou que matassem e atirassem da montanha (que era muito alta) todos aqueles que ainda estivessem vivos: e assim foi feito. E dizem os 
testemunhos que viam como que nuvens de índios lançados do alto da montanha, às vezes setecentos homens juntos; e, todos caindo, rolavam em pedaços" $^{\prime 4}$

É difícil não ficar estarrecido neste caso - como ocorre, freqüentemente, quando percorremos o início da colonização americana - pelo caráter arbitrário da crueldade. O extermínio com requintes de sadismo não é o único meio de levar os aborígenes a uma obediência estrangeira. O exemplo grotesco e assustador da imagem também é empregado: o corpo esquartejado é a melhor forma de chamar à memória o pavor e a quietude. As partes mutiladas, ou mesmo a própria morte expostas transformavam-se em poderoso ícone, distante, por seu caráter absurdo, de um ponto de vista da razão. "O descobridor, diz Theodoro da Silva, ao matar e fragmentar o 'outro', criava um novo sistema de comunicação, uma nova interlocução em um continente no qual as tradições culturais desafiam, no tempo e no espaço, a 'nobre' civilização do Velho Mundo." ${ }^{5}$

Inegavelmente, a história contém a progressão da racionalidade, mas a ela não pode ser reduzida. Algo de irracional também lhe perpassa. A trajetória humana, antes mesmo de ser pensada como uma progressão certa da racionalidade, é passível de ser interpretada como o local onde se testa os limites e possibilidades de um modelo racional, o sítio no qual se encontra a possibilidade de uma criação imaginária especificamente sua, o que constitui uma origem para a empreitada humana no tempo. A partir desta perspectivas, pode-se perguntar acerca da pertinência de algumas filosofias da história, a hegeliana e a marxista por exemplo: soma e seqüência de ações (conscientes ou não) de uma multiplicidade de sujeitos, determinadas por nexos inevitáveis, e por meio dos quais um sistema de idéias se encarna num conjunto de coisas ou o reflete. Os fatos que aparecem na história efetiva como irredutível, em excesso ou em falta, em relação a este esquema, tornase então escória, ilusão, contingência, acaso - em resumo, ininteligível. 0 que não constitui um escândalo em si mesmo, mas deve sê-lo para um filósofo para o qual o ininteligível é apenas mais um nome do impossível. ${ }^{6}$

Nesta sentido, torna-se pertinente a meditação sobre a seguinte assertiva: "a história da conquista é escrita com imagens". E não poderia ser de outro modo. A imaginação é requisitada em primeiro lugar para informar sobre as novas terras, com no caso da cartografia: "Os mapas sempre traziam figuras que decoravam a imaginação do viajante (...) A iconografia que acompanha- 
va os manuscritos sobre as novas regiões descobertas faziam fervilhar o imaginário do leitor." ${ }^{17}$ Não é por acaso que a impressão é aqui fornecida pelo olho , a janela da alma segundo da Vinci: "Não vês que o olho abraça a beleza do mundo inteiro? É a janela do corpo, por onde a alma especula e frui a beleza do mundo, aceitando a prisão do corpo que, sem esse poder, seria um tormento. Ó admirável necessidade! Quem acreditaria que um espaço tão reduzido seria capaz de absorver as imagens do universo?" - diz o gênio italiano. E completa mais à frente, especificando a capacidade singular deste sentido: "O que o olho não faz? Desloca homens de leste para oeste, inventou a navegação e ultrapassa a natureza cujas obras são finitas, enquanto aquelas que o olho comanda às mãos são infinitas."8

Mas, a visão por si mesma é ambígua, quando falamos da apreensão do real. A visibilidade engana necessariamente, uma vez que nela pode se dar a hipo-crisia. Qualquer homem, dominado pelos seus pendores pessoais, pode representar a farsa do respeito à lei, pode parecer seguir suas diretrizes, repetindo a sua letra, mas distorcendo-lhe o espírito. A hipo-crisia é um brilho falso. A língua alemã grafa, para dar conta de seu significado, a palavra Gleisnerei, poder de dissimular, cujo antônimo é justamente o vocábulo Glänzen, brilhante. ${ }^{9}$ A hipocrisia é um brilho excessivo que faz o sujeito distrair-se, escapando para o exterior, sem dominá-lo. O mundo parece-lhe mascarado, e a vida um teatro.

Não seria demais buscar um exemplo na política, para entender o fenômeno visual para a história, as duas áreas se interpenetram e são complementares. A vista, sobretudo no mundo político, é envolvida por uma infinidade de acréscimos, maquiagens que tendem a magnificar os homens que estão diante de nós. Pascal utilizou a idéia ótica da diferença entre o que o olho vê e a estrutura real das coisas, aplicando-a à política, entendida aqui como espetáculo. Os potentados se enfeitam para excitar a imaginação dos súditos, e não para corrigi-la. Os motivos para isto são bastante claros na pena de Pascal: nunca a Razão supera a imaginação, enquanto a imaginação desmonta freqüentemente a razão do seu trono. Estas inversões entre as faculdades, permitem subverter o mundo político, estabelecendo a estabilidade do mundo. O hábito de ver os reis acompanhados de soldados, tambores, oficiais, e toda as coisas que dobram o humano para o respeito e o terror, fazem com que seu rosto, quando ele está, às vezes, só e sem seus acompanhantes e adereços, imprima a seus súditos o respeito e o medo, pois 
não estão separados, no pensamento, suas personagens de seu séquito, que se vêem ordinariamente associados. E o mundo, que não sabe que tal efeito vem do costume, acredita que ele origina-se numa força natural. ${ }^{10}$

A consolidação do domínio parece, nesse momento, fundamentar-se numa pedagogia da violência (Zucht) que não dispensa o imaginário. As cordas que ligam uma a outra, são as da imaginação. Por isso, escolhe "acertadamente" o conquistador quando castiga para exemplificar. "O descobridor, irritado com a impossibilidade de reprodução do padrão europeu, utilizavase da destruição como exemplo. "11 O exemplo, ou melhor, a fixação de uma imagem simbólica, assume o estatuto de solidificador da conquista. É imperioso deslocar o sentido do índio senhor da terra (a autoctonia lhe conferia tal direito, para o do índio servo do europeu, estrangeiro e o novo senhor das novas terras. A imposição e a hipocrisia são claras: castiga-se, mata-se e fere-se o que fora estabelecido consuetudinariamente, em nome do progresso e da civilização. Pela força, quer das armas, quer da persuasão através do exemplo, é preciso destronar um poder e uma cultura que não correspondem aos moldes do subjugador. Impossível não retomar Pascal: "a força sem a justiça é tirânica." ${ }^{12}$ Quando o forte armado possui seu bem, aquilo que lhe pertence não corre risco. Neste sentido, o europeu vinha muito bem armado, trazia a cruz e a espada, pois sabia que "a força é a rainha do mundo e não a opinião". "Mas a opinião, continua Pascal, é que usa a força. Esta é que faz a opinião. A fraqueza é bela, segundo opinamos. Por quê? Porque quem quiser andar na corda bamba estará sozinho."13 O nosso "fraco" índio estava (e está ) sozinho em sua selvageria. Estado, aliás, que de certa maneira, Ihe foi imputado, não somente no sentido de que é a dele, mas porque ele teria podido não produzi-la. "Las Casas questiona, descrevendo os massacres. Usa a descrição do cadáver para demonstrar como não se obedecia à determinação divina. A força que impulsionou o morticídio em sua narrativa não faz parte de um suposto 'destino selvagem' a que a população nativa estava predestinada. Ao contrário, institui, como selvagem, pelos atos que cometeu, o herói da cena européia." ${ }^{14}$

Por fim, deve-se levar em conta que o vasto sistema de relações simbólicas foi sendo elaborado ao longo dos séculos. Isto implica levar também em conta a noção de tempo do contexto. "Uma concepção de tempo regida pela idéia de eternidade afastava o desejo de ruptura e permitia aos colonizadores escrever poemas na areia, olhar sucessivamente as ondas apagarem tudo 
sem que isso gerasse uma ponta de ansiedade, de pressa; sem que isso representasse a menor perda de tempo." ${ }^{15} \mathrm{O}$ tempo é imagem - figura do nãotempo. Por isto, Kant, seguindo Aristóteles, coloca que representamos o tempo pelo puro não-tempo, isto é, a linha; diferentemente da espiral: símbolo do movimento ascensional. Só pode haver tempo se há emergência do outro, do que de nenhuma maneira é dado com com o que é, não forma unidade com este. $O$ tempo é emergência de figuras outras. Os pontos de uma linha não são outros; são diferentes pelo que eles não são - seu lugar.

Com efeito, os pontos levantados aqui buscam o questionamento de um projeto ocidental de uma história universal orientada pela razão. Houve-se falar de uma crise deste modelo. Mas, será que realmente fracassou este projeto em seus moldes especulativos? Existe realmente crise na maneira de conceber a história de um ponto de vista do que era sentido para os ocidentais, deveria ter sentido também para os outros povos? Estas são questões que ainda ocuparão, por muito tempo, as inquietações filosóficas. Este pequeno artigo terá alcançado seu objetivo, se conseguir chamar à atenção para a falta de unanimidade quanto à racionalidade da história. Esta parece não ser regida por leis imutáveis. Talvez continuemos achando que a história caminha para o melhor, apesar das atrocidades implementadas por seus protagonistas. Mas isto não passa de crença. Nada nos autoriza a tornar esta idéia uma certeza. Os humanos, feitos imagem e semelhança de uma perfeição, parecem descobrir que na sua trajetória, nada lhes garante um sucesso permanente em seus empreendimentos. Há sempre o risco do retrocesso. A perfeição, da qual eles se fazem imagem, aparece impotente em dados momentos, frente à surpresa de uma recaída na ignomínia. Desta forma, a história continua sendo um campo de experimentação: nele o homem testa sua capacidade de progredir sempre, faz e refaz constantemente as suas imagens. 


\section{NOTAS}

1 HEGEL, G.W.F. Jenenser realphilosophie. (1805 -1806). (Tradução K. Papaioannou). Paris, 1962, p. 180.

2 CASTORIADIS, C. A instituição imaginária da sociedade. (Tradução Guy Reynaud). Rio de Janeiro: Paz e Terra, 1982. p. 154

3 Cf. Revista VEJA de 16 de outubro de 1991. Ano 24, no 42, p.81

4 Brevíssima relação da destruição das Índias ocidentais; o paraíso destruído. Porto Alegre, L\& PM, 1985, p. 148-50

5 Descobrimentos e Colonização. São Paulo, Ática, 1989, p.60

6 A este respeito ver CASTORIADIS, C, op. cit. p. 203 e segs.

7 THEODORO DA SILVA, Janice, op. cit., p. 39 - 41

8 DA VINCI, Leonardo. Traité de la peinture. Paris : Berger-Levrault, 1987. pp. 89-90

9 A respeito desta análise, ver ROMANO, Roberto. Kant e a Aufklärung. In: FAVARETTO, Celso. (org) Epistemologia das ciências sociais. São Paulo: EDUC, 1985. p. 36 e segs.

10 Cf. PASCAL, B. Pensée ( $\left.n^{\circ} 44\right)$. Paris : Éditions du Seuil, 1962

11 THEODORO DA SILVA, Janice, op. cit. p.53

12 PASCAL, B. Pensée ( $n^{\circ} 103$ )

13 id. ibid. $n^{\circ} 554$

14 THEODORO DA SILVA, Janice, op. cit. p. 63

15 id. ibid. p. 36 